\title{
UNITED NATIONS INVOLVEMENT WITH THE ACT OF SELF-DETERMINATION IN WEST IRIAN (INDONESIAN WEST NEW GUINEA) 1968 TO 1969
}

\author{
John Saltford
}

\section{Introduction}

This paper, based mainly upon previously classified United Nations documents, will seek to re-examine the events surrounding the Act of Free Choice which took place in West New Guinea in July and August 1969. In particular, I wish to look at the role of the United Nations and consider whether or not it fulfilled its responsibilities towards the Papuan people.

The origins of UN involvement in West New Guinea begin with the formation in 1949 of the UN Commission on Indonesia. This set up the "Round Table Conference" at The Hague which resulted in the agreement to transfer sovereignty from the Dutch to an Indonesian federation led by President Sukarno.

During the negotiations, the Netherlands had insisted on retaining sovereignty over West New Guinea, a position condemned by Indonesia as the continuance of Dutch colonialism and a "troublemaking anachronism." 1 The Hague argued the West

${ }^{1}$ Memo of a conversation in Washington between William Lacy (Assistant Chief of Staff Southeast Asian Affairs), Jacob Beam (American Consul General designate at Batavia), and Soedjatmoko (representative of the Indonesian Republic), September 14, 1949, in US Foreign Relations 1949, vol. VII, Indonesia (Washington, DC: Department of State Printing Office). 
72 John Saltford

Papuans had little or no connection with the Asians of Indonesia. They also claimed that they had only administered West New Guinea from Java because they did not consider it practical to appoint a separate governor and administration for a territory with only a small Dutch presence. Nonetheless, Jakarta claimed that West New Guinea was an integral part of the Dutch East Indies and should therefore be part of Indonesia. Further talks were held on the issue in December 1950, but no agreement was reached.

By 1957, Indonesia had unsuccessfully submitted four resolutions on their claim to the UN General Assembly. They now turned to what John Reinhardt describes as the third and final phase of the West Irian dispute, a skillful mixture of diplomacy and threats of military force. ${ }^{2}$

In 1961 this campaign had become a matter of some concern to the newly elected President J. F. Kennedy. Although hostile to Sukarno, he was more prepared than his predecessor to seek a resolution to the dispute. Policy makers in Washington were concerned about Jakarta's massive Soviet-backed increase in military expenditure. Howard Jones, US Ambassador to Jakarta, later wrote:

Sukarno understood the tactics of realpolitik. He was a master of painting himself into a corner and waiting for someone to rescue him. In this situation, with the help of the Russians, he created a real threat of war. It was not a bluff. ${ }^{3}$

Eventually Washington decided that the only way to avoid a Dutch/Indonesian war on a seemingly irrelevant issue was to persuade the Dutch to accept a compromise involving a transfer of sovereignty to Indonesia, linked to some form of selfdetermination. As one US official wrote in February 1962:

I can't blame Dutch for doubting that Indos have any intention of allowing genuine plebiscite five years or so from now. But the important thing is that some such Indo promise is the essential face-saving device Dutch have been seeking. We must get them to take it as best they can expect. ${ }^{4}$

Eventually, The Hague was persuaded to accept such a solution and on August 15, 1962, they signed the New York Agreement with Jakarta. ${ }^{5}$ In what was in effect a facesaving measure for the Dutch, the territory was not directly transferred to Indonesia. Instead, under the Agreement, a temporary UN administration (UNTEA, United Nations Temporary Executive Authority) was established to run the territory for a minimum of seven months. There was no maximum limit set, but in fact the UN withdrew on May 1, 1963 as soon as the minimum period had been completed. At no

\footnotetext{
2 John Reinhardt, Foreign Policy and National Integration: The Case of Indonesia. Monograph Series no. 17, (New Haven: Yale University South East Asian Studies, 1971), p. 67.

${ }^{3}$ Howard P. Jones, Indonesia the Possible Dream (New York: Harcourt Brace Jovanovich, 1971), p. 203.

${ }^{4}$ Robert Komer, National Security Council Staff to C. Kaysen, presidential assistant for National Security Affairs, February 2, 1962, in US Foreign Relations 1961-1963, ed, Ed. Keefer, vol. XXIII, Southeast Asia (Washington, DC: Dept. of State Printing Office, 1994), p. 512.

${ }^{5}$ For a detailed analysis of US involvement in the Dutch/Indonesian negotiations of 1962, see Terrence Markin, "The West New Guinea Dispute. How the Kennedy Administration Resolved that 'Other' Southeast Asian Conflict" (PhD dissertation, Johns Hopkins University, 1996).
} 
point in the negotiations or the decision-making process were any West Papuans involved. ${ }^{6}$

Under the terms of the 1962 New York Agreement, this temporary UN administration was only the first part of a process that would ultimately lead to the Papuan people of West New Guinea exercising their right to self-determination.

\section{Situation in 1968}

In August 1968, a UN team returned to the territory, now renamed West Irian by Jakarta. Led by the Bolivian diplomat Fernando Ortiz Sanz, its responsibility under the Agreement was to "assist, advise and participate" in the act of self-determination planned for the following year.

By the time Ortiz Sanz's UN team arrived, the territory had already experienced five years of Indonesian rule and was facing serious economic and political problems. Peter Hastings, one of only two Australian journalists to be allowed to visit since 1963, gave a damning assessment, despite his support for continued Indonesia control:

The simple fact is that, since the Dutch departure, the Indonesian Government has done little or nothing until this year to develop the country or to give the Papuans any substantial economic development projects or any real degree of political participation. Papuan feeling is running high.?

British Embassy communications from Jakarta reported that they were briefed by a US Consular official, Reynders, who also visited the territory in early 1968. Following his return to Jakarta at the end of March, Reynders reported that Indonesia simply did not have the economic resources necessary for the proper development of West Irian. Commenting on the enormity of the problem he wrote, "The sort of sum required for a proper development of the country is, and will remain, completely beyond Indonesia's means." 8 He also believed that Indonesia did not have the economic or military resources necessary to deal with the security threat posed by "Free Papua" rebels of the OPM (Organisasi Papua Merdeka, Free Papua Movement):

The Indonesians have tried everything from bombing them with B-26s, to shelling and mortaring them, but a continuous state of semi-rebellion persists. Brutalities are undoubtedly perpetrated from time to time in a fruitless attempt at repression. ${ }^{9}$

Even the Indonesians admitted privately that the situation in West Irian was grave. In May 1968, an Indonesian Ministerial delegation led by the Sultan of Yogyakarta made a visit to assess the situation. On their return to Jakarta, the delegation briefed

\footnotetext{
${ }^{6}$ For a brief description of the UN administration of West New Guinea (UNTEA) October 1, 1962 to May 1, 1963, see John Saltford, "Subjects of the Secretary-General West New Guinea 1962 to 1963," Pacific Islands Monthly (Fiji, January 2000): 48-49.

7 Peter Hastings, "West Irian. A Ticking Time Bomb," in Australian, August 5, 1968.

${ }^{8}$ Report of a conversation between Reynders, US Embassy, Jakarta, and Ian Morgan, British Embassy, Jakarta, April 9, 1968. Public Record Office (hereafter PRO) UK. FCO 15/162. DH1/7.

${ }^{9}$ Ibid.
} 
74 John Saltford

the press on their success in dealing with the various problems that they had identified in the territory. In reality, they were shocked at what they had seen. A British Embassy cablegram in July informed London that:

... the visit was chiefly significant in providing members of the Cabinet with a first-hand account of the immensity of the economic problems and a demonstration of the unpopularity of the military and civil authorities which rule the territory. ${ }^{10}$

\section{Strength of Indonesia's Position}

The New York Agreement referred to an opportunity to "exercise freedom of choice," and of consultations with "representative councils" on procedures and methods to be adopted for "ascertaining the freely expressed will of the population." At no point were the critical words "referendum" or "plebiscite" mentioned.11 Nonetheless, Article XVII of the Agreement states that all adults from the territory were eligible to participate in the act of self-determination, "to be carried out in accordance with international practice." Although no definition of what this meant was given, the phrase is of central importance when considering whether or not the terms of the agreement were ever legitimately fulfilled.

Suharto was prepared to take full advantage of the deliberately vague terminology in the Agreement. He was also aware that, with the possible exception of China, ${ }^{12}$ no major power had any interest in opposing their position on West Irian. Since the signing of the Agreement in 1962, Washington had shown little interest in the issue and had apparently rebuffed suggestions by both the Dutch and the Australians that they should "concern themselves rather more closely" in issues having to do with the Act. ${ }^{13}$ Further evidence of this US position was given by Edward D. Masters, at the US State Department. In a conversation with a British diplomat in June 1969, he commented that Washington saw little merit in getting involved in the "niceties of ascertainment," which might lose them good will in Jakarta to no advantage. He then added "the State Department were themselves faced by some criticism from the Senate but it was unlikely to amount to very much."14 Despite Suharto's violent suppression of the Indonesian Communists, the Soviets were mainly uninterested in criticizing Jakarta for its dealings with the territory, particularly as they had been Indonesia's key ally in its campaign for West Irian. There was some condemnation in Soviet publications of

\footnotetext{
${ }^{10}$ I. J. M. Sutherland, British Embassy, Jakarta, to Donald Murray, Foreign Office Southeast Asian Department (SEAD), July 2, 1968. PRO: FCO 15/189 DH1/7.

11 New York Agreement, August 15, 1962, Article XVIII.

12 US Jakarta consular official Reynders believed that the Free Papua Movement (OPM) could probably get arms from Communist China if necessary. Quoted in Morgan, April 9, 1968. PRO: FCO 15/162; Peter Hastings referred to the belief by many Indonesian officials that the OPM was funded by China which he thought feasible. "The Money and Strength behind the Militant Groups" Australian, August 6, 1968.

${ }^{13}$ Information given by La Porta, First Secretary US Embassy, Jakarta, to Alan Mason, British Embassy, Jakarta. Contained in a letter from mason to David F. B. Le Breton, South West Pacific Department (SWPD) of the British Foreign Office, June 10, 1969. PRO: FCO 24/448 (FWD 1/4).

${ }^{14}$ P. R. Spendlove, British Embassy, Washington, to K. Hamylon-Jones, SEAD Foreign Office, June 3, 1969. PRO: FCO 24/448.
} 
Suharto "cheating the Papuans who long for genuine independence,"15 but as one British official, David F. B. Le Breton, remarked:

... there are signs that the Communist [states] would like to mend their fences with [Jakarta] and for that reason they may prefer not to do anything which would worsen their relations with Indonesia at the present time. ${ }^{16}$

Another British official, I. J. M. Sutherland, commented in April 1968:

The strength of the Indonesian position lies in the fact that . . . they must know that, even if there are protests about the way they go through the motions of consultation, no other power is likely to conceive it as being in their interests to intervene. ... I understand that the exiles may find some support in the Australian press. But I cannot imagine the US, Japanese, Dutch, or Australian Governments putting at risk their economic and political relations with Indonesia on a matter of principle involving a relatively small number of very primitive people. ${ }^{17}$

Three months later these sentiments were echoed in a British Foreign Office communication:

The plain fact is that there is no other solution than for Indonesia to keep West Irian; no one is thinking in different terms; and no responsible Government is likely to complain so long as the decencies are carried out. ${ }^{18}$

Significantly, this attitude was shared by the Australian Government, the only Western power with any remaining direct interest in the issue (Australian New Guinea shared a border with West Irian). In late May 1968, a British diplomat, Donald Murray, reported that from Australia's point of view, "... the more quietly the act of self determination passes off next year the better."19

Under the terms of the Agreement, a number of UN experts were to have remained in the territory following the Indonesian takeover to "advise and assist" the authorities in general preparations for the eventual act of self-determination. These experts, with several years experience in the territory, would have been an invaluable asset to Ortiz Sanz on his arrival. Unfortunately for him, this part of the Agreement was never fulfilled and it was a point that he was to comment on in his report to the United Nations General Assembly (UNGA) in November 1969.20 The reason for this was that

${ }^{15}$ V. Kremenyuk, "Referendum in West Irian," International Affairs (Moscow, January 1969): 93. Quoted in Van der Kroef, "Indonesia and West New Guinea," Orbis (Quarterly Journal of World Affairs. Foreign Policy Research Institute, University of Pennsylvania, Philadelphia, PA) XIV,2 (Summer 1970): 386

${ }^{16}$ D. F. B. Le Breton to Richard Neilson, British High Commission, Canberra, July 17, 1969. PRO: FCO 24/448; Sir Patrick Shaw, Australian Ambassador to the UN, New York, to Department of External Relations, Canberra, September 4, 1969. National Archives of Australia, Canberra (hereafter NAA). Extracts of early release documents kindly given to author by Anthony Balmain, SBS Television, Australia.

${ }^{17}$ I. J. M. Sutherland to D. Murray, Foreign Office Southeast Asian Department, April 30, 1968. PRO: FCO 15/162 DH1/7.

${ }^{18}$ D. Murray, Foreign Office Southeast Asian Department, July 26, 1968. PRO: FCO 15/162 DH1/7.

${ }^{19}$ D. J. Wyatt, British High Commission, Canberra, to D. Murray, Foreign Office Southeast Asian Department, May 25, 1968. PRO: FCO 15/162 DH1/7.

20 United Nations General Assembly Official Records. Agenda Item 98, Annexes, 24 Session; "Agreement Between the Republic of Indonesia and the Kingdom of the Netherlands concerning West New Guinea (West 
76 John Saltford

Jakarta did not respond to Secretary-General U Thant's initial proposals for their deployment, and he in turn reportedly "did not intend to make too much of it."21

\section{Ortiz Sanz's Arrival}

On August 23, Ortiz Sanz arrived in West Irian and embarked upon a ten-day, three thousand mile tour of the territory by air. Accompanying him throughout was a team of eight Indonesian officials led by Sudjarwo Tjondronegoro, Jakarta's representative for West Irian affairs. On his return, Ortiz Sanz wrote a report for Secretary-General U Thant in which he praised the work of his Indonesian hosts:

the Government, must be given credit for progress in elementary education, the process of assimilation through use of a common language [Indonesian], school integration and apparent efforts at fraternisation. ${ }^{22}$

He also added:

We know in advance that the principle of "one man one vote" cannot be applied in all areas of the territory, both on account of the terrain and the lack of sophistication of vast segments of the population.... We also know that the Indonesian Government, which seems not to be very sure about the results of the consultation, will try, by all means at its disposal, to reduce the number of individuals, representatives, and institutions to be consulted.23

To counter this predictable move by Indonesia, Ortiz Sanz promised that he would endeavor to enlarge the number of Papuans engaged in deciding the issue so that, in his words, the UN could prove that they did indeed try "to provide as democratic a basis as was possible to ascertain the real will of the population." 24

Although Ortiz Sanz spent very little time in the territory during 1968, the Indonesians were still uncomfortable about his presence. In December, they complained to his superiors in New York that he had become a focus of attention to the Papuans and was causing a "certain excitement" which was obstructing the "smooth running" of the territory. It is true that, despite being constantly accompanied by Indonesian officials, Ortiz Sanz was approached by at least twenty-six Papuans who managed to pass him petitions and letters, most of which condemned Indonesia and called for a genuine referendum in the territory.

Importantly, Jakarta also objected to the UN's intention to send up to fifty staff members to West Irian. This number was later reduced to twenty-five, but in the end

Irian)": Report by the Secretary-General regarding the Act of Self-Determination in West Irian. Document A/7723 (November 6, 1969), Annex I, report by the Representative of the Secretary-General in West Irian, paragraph 11.

21 Memo from D. Hay, Australian Mission to the UN, to Department External Affairs, June 18, 1964. NAA: A1838/280, 3036/6/1 pt. 83 .

22 Ortiz Sanz to U Thant, September 7, 1968. UN Archives, New York (hereafter UN), Series 100, Box 1, File 3.

23 Ibid.

24 Ibid. 
only sixteen UN staff members were employed, and these included administrative personnel. Looking back, it seems incredible that the UN agreed to limit the number of its officials to such a small, token figure. By way of comparison, the UN mission to organize and monitor the August 1999 referendum in East Timor totaled upwards of one thousand individuals, including several hundred police and hundreds of electoral officials. While Ortiz Sanz's team had the more limited responsibility of "advising, assisting and participating" in the Act of Self-Determination, it operated in a territory many times the size of East Timor. Both territories were engaged in an act of self determination, but the comparison demonstrates the immense difference between a genuine attempt to monitor a democratic referendum and one that was not genuine.

In his initial discussions about the method to be used for the Act, Ortiz Sanz told the Indonesians that while officially he could only suggest the universally accepted system of "one man one vote," he was quite prepared to agree to a "mixed" system. By this he meant that the electorate in certain urban areas would be allowed to vote directly, while people in the rural areas would rely on some form of "collective consultation." On this issue he asked Jakarta to at least "meet him half way," because, he declared, it would be the minimum requirement to satisfy world public opinion. ${ }^{25}$

It is not surprising that Indonesia ignored his suggestion, since there is evidence senior Dutch and UN officials had already agreed with Jakarta as early as 1963 to a method for self-determination which did not involve any direct voting by the population. In May 1963, Australia's Washington Embassy forwarded information to Canberra which it had received from the Americans:

The Dutch and Indonesians have apparently been sounding each other out on the question of the form of the self-determination exercise. The Dutch apparently are prepared to agree to the exercise taking some form other than a plebiscite. .. . Narasimhan's [U Thant's Indian chef de cabinet] view is that the Act might take the form of consultation with local councils and village representatives. ${ }^{26}$

A year later, Jose Rolz-Bennett, the Guatemalan Under Secretary-General for Special Political Affairs, made a similar suggestion to the Indonesians during a visit to West Irian and Indonesia. ${ }^{27}$

On the issue of political freedoms, Indonesia was specifically obligated under Article XX of the Agreement to "guarantee fully the rights, including the rights of free speech, freedom of movement and of assembly, of the inhabitants of the area." Commenting upon this, Ortiz Sanz warned Jakarta that without these rights and freedoms, the international community would not be satisfied that a "fair and truly democratic judgment had been made by the Papuans." 28 At the same time however, he

25 Ortiz Sanz to Indonesian Ambassador Sudjarwo Tjondronegoro, November 21, 1968. UN: Series 100 , Box 1, File 5.

26 Australian Embassy, Washington, to Department of External Affairs, May 21, 1963. NAA: A1838/280, $3036 / 6 / 1$ pt. 83.

27 Australian Embassy, Jakarta, to Department of External Affairs, June 12, 1964; Memo from Australian Mission to the UN to Department of External Affairs, June 16, 1964. NAA: A1838/280, 3036/6/1 pt. 83.

${ }^{28}$ United Nations General Assembly Official Records. Agenda Item 98, Annexes, 24 Session; "Agreement Between the Republic of Indonesia and the Kingdom of the Netherlands concerning West New Guinea (West Irian)": Report by the Secretary-General regarding the Act of Self-Determination in West Irian. Document 
78 John Saltford

assured Sudjarwo that Indonesia "has the absolute right to take all the measures it deems necessary to maintain internal order." 29

In fact, under the Agreement Indonesia did not have the absolute right to do as it chose, if, by its actions, it undermined the rights and freedoms of the Papuans. In reply, Sudjarwo thanked Ortiz Sanz for not questioning Indonesia's security measures, adding that economic difficulties encouraged agitation and "Many simple-minded people get easily affected by this kind of cheap propaganda and incitement." 30

Whether or not nationalism is an incorrect term to apply to the political aspirations of a predominantly traditional tribal society like West Irian, reports by various foreign visitors are consistent in their conclusions that the overwhelming majority of Papuans did not want to be ruled by Jakarta. In one example, a British journalist, Garth Alexander, visited the territory in early 1968 and briefed British officials on his return:

Probably the most striking feature of Alexander's report was the further confirmation of what we have been told before that the majority of the West Irianese . . . are very far from wishing to become integrated with the Republic of Indonesia. Of all the people he spoke to, and he met between three hundred and four hundred, none was in favour of such a solution. The impression he has is that the Papuans loathe the Indonesians, perhaps in the same degree and as a direct consequence of the way in which the Indonesians have despised and belittled the Papuans. ${ }^{31}$

A second example is contained in a July 1969 report by Jack W. Lydman of the US Embassy, who cited members of Ortiz Sanz's UN team who had privately conceded that 95 percent of the Papuans supported the independence movement. ${ }^{32}$

At the end of 1968, Ortiz Sanz and a handful of his team members went on a second tour of West Irian lasting just over three weeks. On returning to Jakarta, he reported to his superiors that they had been followed everywhere by Indonesian officials, and as a consequence, had found it very difficult to have any free contact with the local population. Despite this, he was aware of anti-Indonesian feelings, but his report shows that he wished to ignore Papuan opposition to Indonesia's rule insofar as that was possible.

Of course, when the moment arrives, it would be very difficult, indeed, to assess the real importance of such anti-Indonesian sentiment since, as you are very well aware, only a very insignificant percentage of the population is capable of or has interest in engaging in any political actions or even thoughts. ${ }^{33}$

A/7723 (November 6, 1969), Annex I, report by the Representative of the Secretary-General in West Irian, paragraph 57.

${ }^{29}$ Ortiz Sanz to Indonesian Ambassador Sudjarwo Tjondronegoro, November 21, 1968. UN: Series 100,

Box 1, File 5.

${ }^{30}$ Indonesian Ambassador Sudjarwo Tjondronegoro to Ortiz Sanz, November 21, 1968. UN: Series 100, Box 1, File 4.

31 Mason to D. F. B. Le Breton, April 3, 1969. PRO: FCO 24/447.

32 Summary of Jack W. Lydman's report, July 18, 1969 in NAA. Extracts given to author by Anthony Balmain.

33 Ortiz Sanz to Rolz-Bennett, December 18, 1968. UN: Series 100, Box 1, File 3. 
Concluding his report, he added:

The tour has confirmed my initial impressions ... that the implementation of the provisions of the New York Agreement relating to self-determination "in accordance with international practice" is, indeed, impossible. ${ }^{34}$

In reply, Under Secretary-General Rolz-Bennett agreed and wrote that "the lack of development of the population, stood out all too clearly." 35

This willingness by the UN Secretariat to abandon the minimum safeguards contained in the Agreement was characteristic of its attitude towards the issue throughout its involvement with West Irian. In effect, Washington had given the UN the awkward task of providing a veneer of respectability for what was simply the transfer of control of West Irian from one foreign power to another. As Terrence Markin comments:

The Americans, who had repeatedly assured the Netherlands [before the settlement] . . . that they would "stand accountable to our principles" by insisting on a self-determination process that was "a reality and not a mockery," began shortly after the signing [of the New York Agreement] to argue that the responsibility for ensuring a fair exercise really lay with the UN and the Netherlands. Around the same time the Dutch were losing much of their will to press this issue. ... And with neither the US nor the Netherlands pressing the issue, the UN had little incentive to do much. ${ }^{36}$

\section{Indonesia Rejects the "Mixed Method"}

The beginning of 1969 was marked by the surrender of the Mandatjan brothers, rebel leaders from the far west of the country who had been fighting the Indonesians for the past two years. By mid-January, however, rebellion in the area erupted again as around two thousand Arfak tribesmen rose up under the new leadership of Frits Awom. In response, Jakarta was forced to transfer two additional infantry battalions to the region from South Sulawesi. ${ }^{37}$

Meanwhile, at a meeting in New York in late January, Sudjarwo informed the Secretary-General that Jakarta had rejected Ortiz Sanz's plan to adopt a "mixed system" for the Act. ${ }^{38}$ However, the UN Secretariat's apparent prior agreement with Jakarta in 1963 to dispense with any direct voting suggests the plan might simply have been a public gesture to demonstrate UN efforts to ensure some democratic involvement in the Act.

\footnotetext{
34 Tbid.

35 Rolz-Bennett to Ortiz Sanz, January 2, 1969. UN: Series 100, Box 1, File 3.

${ }^{36}$ Terrence Markin, The West New Guinea Dispute, pp. 479-480.

37 Brian May, The Indonesian Tragedy (Boston: Routledge, and London: Keegan Paul Henry, 1978) p. 171; J. Van der Kroef, "Indonesia and West New Guinea: The New Dimensions of Conflict," Orbis XIV, 2 (Summer 1970): 387.

38 Rolz-Bennett to Ortiz Sanz, January 30, 1969. UN: Series 100, Box 1, File 3.
} 
80 John Saltford

An alternative possibility is that Ortiz Sanz was not fully briefed by the Secretariat and was not aware of its previous discussions with Jakarta. In this case his effort to introduce genuine Papuan participation might have been undertaken without proper consultation with $U$ Thant. Evidence of this comes from an Indonesian newspaper in July 1969 which claimed that Sudjarwo had been angered to discover that the "mixed method" was Ortiz Sanz's idea and had not originated in New York. ${ }^{39}$ This scenario would support the position of those who argue that Ortiz Sanz was more a victim of maneuverings in New York and Jakarta, rather than a cynical participant. As Sir Patrick Shaw, the Australian Ambassador to the UN, commented in April 1968 after meeting him, "Ortiz Sanz is a man of goodwill and integrity but I am not sure that he has much conception of the sort of environment in which he will find himself working in West Irian." 40

In meetings held between Ortiz Sanz and the Indonesians during February, Sudjarwo outlined the method which the authorities had decided to adopt. Their chosen option was to enlarge the eight regional councils, already existing in the territory, and create special Assemblies which would then each reach a collective decision on whether or not to remain with Indonesia. ${ }^{41}$ These existing regional councils had been set up by Jakarta when it took over in 1963, and their members were appointed by the authorities. Ortiz Sanz could do little but request that he be given information about all existing councilors to help him determine to what extent they truly represented the population. Sudjarwo agreed, but nothing was ever handed over. 42

Soon afterwards, Sudjarwo gave Ortiz Sanz further information on the selection process to be used to appoint additional members for the planned assemblies. One group would be chosen by existing approved political, social, and cultural organizations. A second group would consist of "traditional" tribal chiefs selected by the existing council members, and a third group was to be elected by the people themselves. ${ }^{43}$

As a result of this, the only potential opportunity for genuine popular participation lay in the election of the third group. In practice however, this method of choosing additional members meant that the Indonesian authorities and the existing Indonesian appointed councils had tight control of the whole selection process for the final "consultative assemblies." As Ortiz Sanz wrote in his final report, Sudjarwo had informed him, "Those few people-possibly existing-not in favour of retaining ties

39 Quoted in a letter from I. J. M. Sutherland, British Embassy, Jakarta, to D. Aiers, SWPD Foreign Office. PRO: FCO 24/449 (FWD 1/4).

40 Sir Patrick Shaw to Department of External Affairs, April 8, 1968. NAA: A452 T29, 68/2581.

41 Decree of the Minister of Home Affairs, Chairman of the West Irian sector No. 31, 1969, on the establishment of the Consultative Assembly for the "Act of Free Choice": Regency Merauke. UN: Series 100, Box 1, File 4

42 Ortiz Sanz to Rolz-Bennett, February 14, 1969. UN: Series 100, Box 1, File 4; Interview with Ortiz Sanz by Dutch Journalist Stephane Alonso Casale, December 15, 1999. Extracts kindly given to author by Casale. See also articles by Casale in NRC Handelsblad (Dutch national newspaper), March 4, 2000.

43 Sudjarwo to Ortiz Sanz, February 18, 1969. UN: Series 100, Box 1, File 5. 
United Nations Involvement with the Act of Self-Determination 81

with the Republic of Indonesia, are ... not organised in legally existing political groups or parties in West Irian." 44

\section{Petitions}

To justify this proposed method for determining the Papuan's response to Indonesian rule, Jakarta consistently claimed that the vast majority of the Papuan population were in favor of staying with Indonesia and did not want the Act to take place. In their General Assembly report they wrote that this view was based upon hundreds of supporting statements which they had received from Papuans. ${ }^{45}$

In private however, Sudjarwo was unhappy about the number of anti-Indonesian petitions which were being sent to Ortiz Sanz and then forwarded on to him. At one point he even complained to the Secretary-General that these petitions were beginning to upset the Indonesian army. ${ }^{46}$

In his final report to the General Assembly, Ortiz Sanz wrote that he had received a total of 179 petitions during his time in the territory, both for and against Indonesia. With regard to the first group-petitions favoring Indonesian sovereignty over West Irian-he said that these came from the regional councils and various officially recognized organizations. They were, he said, written by politically minded and better educated people. At no point in the report did he question whether these were genuine views or simply the result of Indonesian pressure. ${ }^{47}$ In contrast, he was dismissive of the anti-Indonesian petitions, describing them as being often barely intelligible and usually anonymous.

More importantly, he asserted in his official report to the General Assembly that over half the petitions he received were pro-Indonesian. ${ }^{48}$ One has to question why he wrote this, because it was simply incorrect. In the UN archives in New York, details of 156 of the 179 petitions survive, recording all those received up until April 30, 1969. Of these, ninety-five are anti-Indonesian, fifty-nine are pro, and two are neutral. ${ }^{49}$

Therefore, even if all the missing twenty-three petitions were pro-Indonesian, this would mean that over half would still be "anti-." In fact, Ortiz Sanz privately admitted that many of the petitions he received in the final weeks were against Indonesia, so it is reasonable to conclude that in total, at least 60 percent of the petitions delivered to the UN were against Indonesia and in favor of a genuine referendum.

44 UNGA Official Records Annex 1, para. 126.

45 Ibid., Annex 2, para. 24.

46 Rolz-Bennett-Note for the record of the meeting between himself, $U$ Thant, Sudjarwo, and Indonesian Ambassador Abdulgani in New York, January 23, 1969. UN DAG 1/223:9.

47 UNGA Official Records, Annex 1, para. 141.

48 Ibid., paragraphs 142 and 145.

49 Six lists of summaries of political communications from unidentified Papuans to Ortiz Sanz, August 1968 to April 1969. UN: Series 100, Box 1, File 5. 
82 John Saltford

It is not realistic to suggest that Ortiz Sanz simply made a mistake, since the descriptions of each petition are clearly typed and the list is easy to add up. Consequently, either Ortiz Sanz himself chose to mislead the UNGA deliberately, or he was told to do so by $U$ Thant. Whoever was responsible, it is a clear illustration of the UN leadership's collaboration with Indonesia to legitimize the Indonesian takeover of West Irian, at the expense of the Papuans, who thereby lost political rights guaranteed in the Agreement.

\section{Political Prisoners and Political Rights}

Further evidence of this collaboration comes from correspondence between Ortiz Sanz and Sudjarwo on the issue of political prisoners. While Ortiz Sanz acknowledged that the New York Agreement required the release of any political prisoners, he let Jakarta know that he accepted their right to deal differently with those he described as "anti-state." He even went so far as to suggest that it would be better to move such troublesome people out of the territory before the Act was put into effect. ${ }^{50}$

In March 1969, the Dutch privately urged U Thant to consider sending in a UN expeditionary force to ensure that the vote could take place without intimidation from the Indonesian military. ${ }^{51}$ The Secretary-General, however, contested The Hague's assertion that such a deployment was permitted by the Agreement and rejected the suggestion. Ortiz Sanz commented, probably correctly, that it was just a Dutch tactic to enable them to claim that they had at least attempted to protect the Papuans. ${ }^{52}$ Besides, Jakarta would have certainly refused to allow such a deployment.

Nonetheless, Ortiz Sanz did continue to apply what little pressure he could on Indonesia to include some democratic content in the Act. On March 18, he issued a press release in which he declared that Indonesia's chosen method would only be acceptable if it fulfilled three prerequisites:

1. The final consultative assemblies had to have a sufficiently large membership.

2. The assemblies should represent all sectors of the population.

3. The new members of the assemblies should be clearly elected by the people.

He ended by stating that Jakarta had given him official assurances that these prerequisites would be complied with. ${ }^{53}$ Whether this declaration was made widely available to the Papuans is unknown, but if the authorities did not actively cooperate in disseminating the press release, then it is unlikely many Papuans were informed of these prerequisites.

\footnotetext{
50 Ortiz Sanz to Rolz-Bennett, February 14, 1969, UN: Series 100, Box 1, File 4.

51 Rolz-Bennett to Ortiz Sanz (cable No. 125), March 18, 1969. UN: Series 100, Box 1.

52 Ortiz Sanz to Rolz-Bennett (cable No. UNWRI SKU-22), March 29, 1969. UN: Series 100, Box 1.

53 Draft of UN press release, March 18, 1969. UN: DAG 1/ 2.2.3: 9.
} 


\section{Papuan Protest and Continued Indonesian Preparations}

On April 11, the last of the regional councils met to accept officially Jakarta's chosen method for the Act, although they loyally reasserted that the whole exercise was an unnecessary distraction and that West Irian would always be Indonesian.

On the same day, another group of Papuans gathered outside Ortiz Sanz's Jayapura residence to call for a genuine referendum. Ortiz Sanz addressed the crowd of several thousand and asked them to disperse, while assuring them that the UN would continue trying to ensure the rights and freedoms to which they were entitled. Immediately afterwards he contacted U Thant to tell him how he had successfully persuaded the Indonesian military not to intervene. He then added:

The outcome of this incident has shown for the first time in West Irian the possibility of peaceful democratic demonstrations by the population and evident good-will on the part of high ranking Indonesian military commanders.

Everything is now quiet. ${ }^{54}$

Two months later, however, he was forced to revise this positive report and to inform the Secretary-General that at least forty-three people had been arrested and detained without his knowledge, following the demonstration. .5

Meanwhile, it appeared that the UN's efforts to influence Indonesia were continuing to fail. In mid-April, Ortiz Sanz told Rolz-Bennett that Jakarta had decided that new members of the regional Assemblies would simply be suggested by officially appointed ad hoc committees, rather than elected by the people as previously promised. This was a clear snub to Ortiz Sanz, so soon after his public statement on the importance of elections for the assemblies. In reply, a rather exasperated RolzBennett wrote:

Our initial reaction is that Indonesia may be going too far particularly by its decision to have the additional representatives suggested-which means in fact appointed-by an ad hoc committee. Our Indonesian friends should realise, as you have told them so many times, that the method for the act of free choice should not depart so radically from generally accepted norms of political representation. It is surely not beyond human ingenuity to devise a method whereby the additional representatives would be elected or selected by their respective communities, thus giving an opportunity to the general population to be involved in the act of free choice. .5

\section{Rebellion}

Unease at the developing situation was increased in mid-April when widespread rebellions broke out in the Western Central Highlands. Airstrips were sabotaged and Indonesian officials and military fled the region. On April 23, ninety well-armed

\footnotetext{
54 Ortiz Sanz to Rolz-Bennett (cable No. UNRWI SKU-24), April 12, 1969. UN: DAG 1/ 2.2.3: 9.

55 Ortiz Sanz to Rolz-Bennett, June 14, 1969. UN: Series 100, Box 1, File 4.

56 Rolz-Bennett to Ortiz Sanz, April 17, 1969. UN: Series 100, Box 1, File 2.
} 
Papuan policemen mutinied and joined the OPM. ${ }^{57}$ On April 27, a plane carrying General Sarwo Edhie, the territory's Indonesian military Commander, was hit by gunfire as it flew over the area. Two passengers, including a police inspector, were wounded. In response, the General ordered planes, including at least one B-26 bomber, to strafe Enarotali, and on April 30, Indonesian paratroopers from West Java were flown in. The Indonesian counter attack resulted in around fourteen thousand people fleeing into the bush while skirmishes with the OPM continued..$^{58}$ Elsewhere, nationalist demonstrations were held in Arso, Indonesian troops were attacked near Merauke, and on the Bird's Head peninsula, the Arfak rebellion led by Fritz Awom continued.

Ortiz Sanz's initial reaction to the rebellions was to try and ignore them, and he instructed his staff to refrain from any involvement in the issue. He also informed the press that internal security was a matter for Jakarta and not his business. ${ }^{59}$ This response was not well received by his superiors, and Rolz-Bennett immediately instructed him to obtain full information on the disturbances from Indonesia. ${ }^{60}$ Under pressure from New York, Ortiz Sanz also made a brief visit to the area. On his return to Jakarta he issued a statement to the press claiming that all was now quiet. ${ }^{61}$ In fact, he saw little during his inspection tour and sometimes never even went beyond the airstrip. Furthermore, he had actually written his press statement before his trip commenced. 62

In private, however, he was sufficiently concerned about the general situation so that in mid-May, he requested that $U$ Thant ask Indonesia to delay the Act by three to four months in order "to provide us with a last opportunity for improving the democratic conditions." 63 But the Secretariat had no enthusiasm for this idea, and Rolz-Bennett replied by asking "whether it would in fact be possible to change significantly the conditions in the territory during the period of a suggested postponement."64

\section{UN Pressure on Indonesia}

While General Sarwo Edhie suppressed the rebellions, the UN continued to urge Jakarta to moderate its stance on the Act. A UN report in May of a meeting between $U$ Thant and the Indonesian Ambassador states:

... the Secretary-General emphasised the importance of electing the additional councilors in a way that would ensure that the new councilors would truly

\footnotetext{
57 Robin Osborne, Indonesia's Secret War (Sydney, Australia: Allen \& Unwin, 1985), p. 42.

58 Brian May, The Indonesian Tragedy, p. 173; Carmel Budiardjo and Liem Soei Liong, West Papua: The Obliteration of a People (London: Tapol, 1985), p. 21. May specifically states that a Captain Harsono flying a B-26 Bomber (No. B267) had strafed the town of Enarotali.

59 Ortiz Sanz to Rolz-Bennett (cable No. UNRWI JKT-51), May 8, 1969. UN: DAG 1/ 2.2.3: 9.

${ }^{60}$ Rolz-Bennett to Ortiz Sanz (cable No. 244), May 7, 1969. UN: DAG 1/2.2.3: 9.

61 UNGA Official Records, Annex 1, para. 157.

62 Ortiz Sanz to Rolz-Bennett (cable No. UNRWI JKT-55), May 12, 1969. UN: Series 100, Box 1, File 1.

63 Ibid.

${ }^{64}$ Rolz-Bennett to Ortiz Sanz (cable No. 258), May 16, 1969. UN: DAG 1/2.2.3: 9.
} 
represent the people of their constituencies. This would be the touchstone in the judgement about the fairness and validity of the whole exercise which would be made by member States of the United Nations. ${ }^{65}$

But by the time $U$ Thant made this plea, Indonesia had already begun appointing the new councilors without informing Ortiz Sanz and his team, who were supposed to be monitoring the whole exercise. It was a further embarrassment to the UN's representative, especially as the situation was being reported by some of the foreign press. Ortiz Sanz again appealed to Sudjarwo saying:

I stress the importance of a properly implemented Act of Free Choice because I believe Indonesia wishes a final, and not a temporary, solution to the problem of West Irian. The Indonesian Government should take a calculated risk and allow the opposition the opportunity to express its views. This is the moment for the Indonesian authorities to adopt courageous and generous measures. ${ }^{66}$

Eventually, under pressure from Rolz-Bennett, Ortiz Sanz reluctantly wrote to Sudjarwo urging him to re-stage some of the elections, so that the UN could be there to monitor the process. To his surprise, Sudjarwo agreed, ${ }^{67}$ and between June 26 and July 5 , a selection of fresh elections took place in the presence of UN officials and, occasionally, the foreign press. Despite this, by the end, UN officials only actually managed to witness the election of 195 out of the 1,022 Assembly Representatives who eventually took part in the Act.

Nonetheless, it was to be the only occasion in which UN pressure on Indonesia had any effect during the entire period, and Ortiz Sanz made much of it in his final General Assembly report. Absent from this report, however, is any description at all of the election meetings themselves, and the reason for this omission becomes clear from reading the accounts given afterwards by the few members of the foreign press present, and by the locals themselves. A typical example was described by the Australian journalist Hugh Lunn, who witnessed one election in Biak which was also attended by Ortiz Sanz himself.

The election, he said, consisted of a group of Indonesians walking into a silent crowd of Papuans and choosing six men that they themselves had selected. Hugh Lunn then described how Indonesian soldiers arrested three Papuans who displayed placards demanding a plebiscite. One journalist appealed to Ortiz Sanz to intervene, but he simply said that he was there just to observe.68

When one considers the importance attached by the UN to these elections, which were represented as the "touchstone" on which the democratic credentials of the whole Act would be judged, it is hard not to conclude that their efforts were completely unsuccessful. Even in those few elections witnessed by UN observers, it was obvious that genuine democracy had no perceivable part to play in the exercise. With the failure of his final attempt to create an appearance of democracy, Ortiz Sanz was to

65 Rolz-Bennett to Ortiz Sanz (cable No. 250), May 9, 1969. UN: DAG 1/ 2.2.3: 9.

66 Ortiz Sanz to Sudjarwo, May 27, 1969. UN: Series 100, Box 1, File 5.

67 Sudjarwo to Ortiz Sanz, June 14, 1969. UN: Series 100, Box 1, File 5.

68 Hugh Lunn, Australian, August 21, 1999. 
spend the remainder of his time in the territory collaborating with $U$ Thant and Jakarta in their efforts to conclude the Act with as little controversy as the situation permitted.

\section{UN and Indonesian Collaboration}

The importance attached to this task, and the extent to which it became Ortiz Sanz's only concern, is well illustrated in a letter which he wrote to Rolz-Bennett on June 14. In this letter, Ortiz Sanz revealed that Sudjarwo was "not only concerned, but worried" about two particular points. The first was the attitude of the Netherlands Government towards Indonesia's chosen method for the Act. The second was the contents of the final report which Ortiz Sanz would submit to the UNGA. With regard to the former, Ortiz Sanz declared:

I advised him privately though emphatically that his Government should try to obtain assurances that the Netherlands' Government would not cast any doubt on, or challenge, the Act of Free Choice. This would prevent a heated debate in the General Assembly.

On the subject of his final report, Ortiz Sanz wrote:

... as an expression of my continued co-operation, I offered to show Sudjarwo, on a personal basis, those parts of the report that might be controversial or create discrepancies with the [Indonesian] report. ${ }^{69}$

This is a significant letter for two reasons. First of all, it reveals that Indonesia was genuinely concerned at possible international criticism of their intention to deny the Papuans any genuine self-determination. More importantly, however, this letter provides unambiguous evidence of Ortiz Sanz's direct involvement with Jakarta in measures aimed at minimizing the impact of any international protest at these fundamental breaches of the Agreement. While this level of duplicity and cynicism might be expected from a State in pursuit of its perceived "national interest," it is a completely indefensible mode of action for a representative of the Secretary-General of the United Nations.

However, the Secretary-General himself seems to have made similar suggestions to the Indonesians. At a private meeting held in New York on June 20, U Thant informed Sudjarwo that:

The Indonesian Government would have to consult very diligently with the Members of the General Assembly for the purpose of preventing the submission of a draft resolution touching on the substance of the West Irian matter. ${ }^{70}$

In the last weeks before the Act began, Ortiz Sanz told Rolz-Bennett that the human rights situation was actually getting worse, despite his constant appeals to Jakarta to show restraint. He even twice asked the Indonesians to arrange for him to

69 Ortiz Sanz to Rolz-Bennett, June 14, 1969. UN: Series 100, Box 1, File 4.

70 Rolz-Bennett to Ortiz Sanz (cable No. 337), June 21, 1969. UN: Series 100, Box 1. 
meet with President Suharto so that he could express his concerns. But, as he had to concede in his final report, Suharto was too busy to see him. ${ }^{71}$

\section{The Act of Free Choice}

On July 14, the Act finally began with a meeting of the 175 "consultative assembly" members for Merauke. In addition to Ortiz Sanz and his team, a large group of senior Indonesian politicians and soldiers were present. Also there were the Ambassadors of Australia, the Netherlands, and Thailand, accompanied by Indonesian journalists, officials, politicians, and a small number of foreign reporters. ${ }^{72}$

As was the case with all the other meetings, the assembly members had spent several weeks before the day under guard by the authorities and isolated from the rest of the community. Some assembly members claim that they were threatened and bribed by Brigadier-General Ali Murtopo, Commander of the Army's OPSUS (Special Operations Section), during those weeks when they were under guard. Murtopo had been selected by President Suharto to go to West Irian with a team of military personnel, students, and teachers in order to mount a "hearts and minds" campaign and "make a success" of the Act. According to the Reverend Hokujoku who was a member for Jayapura, Murtopo warned them that Indonesia was a great military power and would not tolerate dissent. If they wanted their own country, he mockingly suggested that they could ask the Americans for a piece of the moon. Hokujoku also described how those Papuans chosen to speak at the meeting were given exact instructions about what to say and were forced by the Indonesians to rehearse their speeches. ${ }^{73}$

In Merauke and elsewhere, the task of the Assembly members, as decreed by Jakarta, was to come to some form of collective decision using a vaguely defined Indonesian method for reaching consensus, known as musjawarah (consultation/ deliberation). What this meant in practice was that a number of senior Indonesian officials addressed the Merauke members telling them that they should, for a variety of reasons, remain with Indonesia. Then, Ortiz Sanz made a brief statement about the importance of their task and reminded them that they were speaking not only for themselves, but for all Papuans. "Do not hesitate to speak the truth and be loyal to the wishes of your own people."

Following these speeches, twenty of the Assembly members stood up one after the other and made a series of almost identical statements. They proclaimed that they had considered themselves as part of Indonesia since 1945, they recognized only one country, one constitution, one flag, and one Government, that of Indonesia. After these statements the Chairman, a Government official, told the other 155 assembly members to stand up if they agreed with their colleagues position. All then stood up.

The Indonesia Minister of Home Affairs then concluded the proceedings by thanking the members for their decision and pledging that Indonesia would fulfill its

\footnotetext{
71 UNGA Official Records, Annex 1, para. 182.

72 Ibid., Annex 1, paragraphs 189-200.

73 Reverend Origenes Hokujoku quoted in Algemeen Dagblad (Netherlands), December 12, 1988.
} 
responsibility to develop the territory economically and in every other respect. West Irian, he promised, would be given autonomy in organizing, coordinating and carrying out this task. ${ }^{74}$

The following day, Ortiz Sanz gave a press conference in which he defended the Indonesian musjawarah system as "practical." He later argued that the option of national independence for West Irian would not be feasible. ${ }^{75}$ The Sydney Morning Herald published an editorial on July 14 which was fiercely critical of the whole exercise and the behavior of its own Government in Canberra:

The last stage in the betrayal of the people of West New Guinea is scheduled to begin today. ... . No amount of word twisting can change the ugly fact that an unsophisticated island people is being quite deliberately and openly cheated of its right, guaranteed by an international agreement reached under the aegis of the United Nations, to decide its own political future. . . . Where else in today's world would the dictum be accepted that a people was too primitive ever to be free ${ }^{76}$

Despite such criticism, the next assembly went ahead as planned in Wamena on July 16 with identical results. ${ }^{77}$

The third assembly meeting took place on July 19 in Nabire in the Western Central Highlands region. According to the journalist Brian May, a recent rebellion had emptied the area of local people to such an extent that the Indonesians had to ship in Papuans from other regions to play the part of Assembly members. ${ }^{78}$ Even so, another journalist, Hugh Lunn, reported that one assembly member managed to contact him to ask whether he could guarantee that there would be no reprisals if one hundred members spoke out against Indonesia at the meeting. Lunn replied that he could not give such a pledge. Another member then slipped him a note to say that the assembly had all been bribed. At the same time, a third member attempted to pass a note to the UN team, but according to Lunn, they refused to accept it. ${ }^{79}$ Despite all this, Ortiz Sanz's official report made no mention of the rebellion or allegations of bribery. ${ }^{80}$ The same day, Jakarta declared that the results so far meant that West Irian had already chosen to stay with Indonesia. The remaining meetings would therefore be nothing more than a confirmation of this result. 81 The next two meetings in Fak Fak and Sorong also followed the same format as the others, with the same speeches and the same pledges of love and loyalty to Jakarta delivered by the handful of Papuans selected to speak.

In Manokwari, while the assembly voted, Papuan youths outside the meeting room chanted "alone, alone." In response, armed Indonesians threw them into the backs of lorries and drove them away. At one point, Hugh Lunn the only foreign journalist

74 UNGA Official Records, Annex 1, paragraphs 189-200.

${ }^{75}$ Australian Journal of Politics and History, vol. XVI (July to December 1969): 9.

76 Sydney Morning Herald, editorial, July 14, 1969.

77 UNGA Official Records, Annex 1, paragraphs 201-207.

78 Brian May, The Indonesian Tragedy, p. 192.

${ }^{79}$ Hugh Lunn, Australian, August 21, 1999.

${ }^{80}$ UNGA Official Records, Annex 1, paragraphs 208-213.

81 Brian May, The Indonesian Tragedy, p. 192. 
present, was threatened with a gun by an Indonesian while he took photos of the demonstration. He then ran inside to inform Ortiz Sanz, but Ortiz Sanz refused to intervene. ${ }^{82}$

On July 31, the Biak meeting followed the same pattern. Meanwhile scores of Papuans on the island were in detention, having been arrested shortly before as a precaution by the authorities in case they disrupted the event. ${ }^{83}$

On August 2, with food, drink and singing laid on, the final Assembly meeting took place in Jayapura. ${ }^{84}$ To celebrate, various Indonesian military officers and officials were then paraded shoulder high by groups of Papuans, in what could be described as a rather tasteless theatrical display of pre-rehearsed jubilation. 85

With the final part of the Act's implementation complete, Jakarta solemnly announced that the legal and final result, in accordance with the New York Agreement, was that all the Papuans had elected to remain with Indonesia.

\section{Aftermath}

On July 17, 1969, a British diplomat with the UK Mission to the UN in New York summed up international opinion. He conceded that some African countries were unhappy about the Act, but concluded:

Our strong impression is that the great majority of UN members want to see this question cleared out of the way with the minimum of fuss as soon as possible... The Arabs and the other Moslem states would certainly support Indonesia strongly. There is, moreover, general recognition, even, according to the Dutch, on the part of the moralistic Scandinavians, that there is no alternative to Indonesian rule. Finally the Secretariat, whose influence could be important, appear only too anxious to get shot of the problem as quickly and smoothly as possible. ${ }^{86}$

Three months later, in November 1969, Ortiz Sanz's final report was presented to the UNGA. In his conclusions, he expressed concern that the political freedoms guaranteed by the Act had not been fulfilled. He also conceded that "certain elements" of the population favored independence. Nonetheless he declared that, "with the limitations imposed by the geographical characteristics of the territory and the general political situation in the area, an act of free choice has taken place in West Irian in accordance with Indonesian practice, in which the representatives of the population have expressed their wish to remain with Indonesia." 87

Technically this was an accurate statement, if by "Indonesian practice" he meant an exercise totally devoid of any genuine democratic content. But the New York

\footnotetext{
82 Hugh Lunn, Australian, August 21, 1999.

83 UNGA Official Records, Annex 1, paragraphs 214-238.

84 Ibid., paragraphs 329-244.

85 Brian May, The Indonesian Tragedy, p. 193.

86 D. Parson, UK Mission to the UN, to D. F. B. Le Breton, July 17, 1969. PRO: FCO 24/449, (FWD 1/4).

87 UNGA Official Records, Annex 1, para. 253.
} 
90 John Saltford

Agreement specified that Papuan self-determination had to be carried out in accordance with "international practice."

Ghana, and several other African countries at the November meeting, condemned the exercise for being undemocratic. They also called for a proper act of selfdetermination to be held in the territory in 1975, on the grounds that the Agreement had not been properly fulfilled. However this amendment to the main resolution on West Irian was defeated by sixty votes to fifteen, with thirty-nine abstentions.

In the end, the General Assembly voted by eighty-four votes to none, with thirty abstentions, to simply "take note" of the Secretary-General's report, and the reports of Indonesia and Ortiz Sanz. ${ }^{88}$

\section{Conclusion}

Whether the Papuans should have had the right to independence is an issue with strong arguments for and against. As Henderson noted in 1973, many newly independent states contain minorities which might have aspirations to independence themselves. But if such separatism were encouraged it could:

... set in train the dissolution of innumerable ethnically complex states whose main claim to unity derives from the colonial mandate. The consequences of this for the stability of the international system could be incalculable. ${ }^{89}$

On the other hand, Mullerson, writing on multi-ethnic states, comments:

when minorities are discriminated against or their identity is threatened by majority policy ... the minority is not participating together with the rest of the population in the ever-continuing and ongoing process of self-determination.... This means that the minority can realize its right to self-determination not in the society as a whole, together with the rest of the population, but only separately. ${ }^{90}$

Finally, in response to an inquiry by $U$ Thant on the legal aspects of the Papuans' right to self-determination, the UN's legal adviser replied in June 1962:

... since President Wilson enunciated the principle of self-determination in 1918, there appears to emerge a strong presumption in favour of self-determination in situations such as that of Western New Guinea on the basis of the wishes of the peoples of the territory concerned, irrespective of the legal stands or interests of other parties to the question. While other factors may also be taken into account, there seems to be a growing practice of recognising that the wishes of the local population should be paramount.91

\footnotetext{
${ }^{88}$ United Nations Official Records: 1812th Plenary Meeting of the UN General Assembly, agenda item 98. A/L576. November 19, 1969.

89 William Henderson, West New Guinea, the Dispute and its Settlement (South Orange, NJ: Seton Hall University Press, 1973), p. 252.

90 Rein Mullerson, International Law, Rights and Politics (London: Routledge, 1994), pp. 77-78.

91 C. Stavropoulos, UN Legal Adviser, to U Thant, June 29, 1962. Attached to back of memo from Stavropoulos to Rolz-Bennett, July 17, 1969. UN: Series 100, Box 2, File 7.
} 
The purpose of this paper, though, was not to discuss the legitimacy of Papuan self-determination, because this right had already been explicitly acknowledged by the Netherlands and Indonesia when they signed the 1962 Agreement. Furthermore, by agreeing to participate in the implementation of this Agreement, the UN Secretariat undertook a responsibility to ensure that it was properly fulfilled. Instead, my intention has been to determine first of all whether the Agreement was properly implemented, and second to assess the UN's role in its implementation.

I would contend that the first part of this does not require an in-depth study of the subject to arrive at an accurate conclusion. A brief examination of the official Secretary-General's November 1969 report is all that is needed to conclude that the Agreement was not fulfilled. Under its terms, the Netherlands, Indonesia and the UN had an obligation to protect the political rights and freedoms of the Papuans, and to ensure that an act of self-determination took place, in accordance with international practice. On both these points, the three parties failed, and they did so deliberately since genuine Papuan self-determination was never seen as an option by any of them once the Agreement was signed.

On the UN's part in the Agreement's implementation, it is clear that the Secretariat's priority throughout was to ensure that West New Guinea became a recognized part of Indonesia with the minimum of controversy and disruption. This was the role assigned to the organization by the Americans in 1962, and U Thant saw no reason not to comply. It was Cold War politics, and the rights of the Papuans counted for nothing. Indeed it would have been extraordinary if things had turned out otherwise.

To fulfill its task, the UN Secretariat tolerated Indonesian interference and intimidation of the population during the temporary UN administration of the territory. Shortly afterwards, it collaborated with the Dutch and Indonesians in agreeing privately to abandon the use of any direct voting system for Papuan selfdetermination. In the year leading up to the Act, the Secretariat's objective was to minimize the potential for international criticism by ensuring the appearance of a sufficient level of genuine Papuan participation, while obtaining the desired result.

To achieve this they made a number of suggestions to Jakarta. Ortiz Sanz's "mixed method" was one example (as previously mentioned, there is some uncertainty as to the plan's origin; it may or may not have been originally devised by Ortiz Sanz). Another was their attempt to make sure that some Papuans participated in the process of selecting additional representatives for the final assemblies. Both $U$ Thant and Ortiz Sanz emphasized privately and publicly their concern that there be some democratic dimension to these selections. In the Secretary-General's final report, much was made of Jakarta's agreement to hold fresh elections in a few of the many areas where no UN officials had been present. In reality, though, this was nothing more than a token gesture, and one can conclude that there was no genuine participation by the people in these selection processes. In the end, the unanimous decision by 1,022 representatives to remain with Indonesia made a mockery of the UN's endeavors, despite an apparent final effort by Rolz-Bennett who, according to Markin, had confidentially urged Jakarta to record some negative votes, "to give the outcome the 
92 John Saltford

appearance of legitimacy."92 One can argue however that the lack of significant international interest in the Act made their failure largely irrelevant at the time.

With the realization that Indonesia was going to ignore their recommendations on this issue, the UN chose to cooperate with Jakarta in its efforts to stifle any international criticism of the way the referendum in West Irian had been handled. In this effort they were assisted by other states including the Netherlands, Australia, and the UK. These countries all privately lobbied other countries, particularly in Africa, which seemed most likely to condemn the result. Furthermore, Ortiz Sanz stated in his report to the UNGA that the majority of petitions he received from Papuans were proIndonesian; he made this assertion despite the fact that he must have known it to be false.

In the end, one can say that Ortiz Sanz's task was a thankless one, since he was condemned by the Indonesian press as a Papuan sympathizer, and criticized by a number of Western diplomats for his timidity in defending the Papuans. To this day however, he maintains that the method adopted was the most democratic possible under the circumstances and that the final result was "wise and sensible."93

To conclude, the UN was an active participant in the systematic undermining of the New York Agreement, but its actions were initiated and supported by Washington, Jakarta, and the Hague. In acting as they did, U Thant and the UN Secretariat allowed the UN to involve itself in a dishonest process which deliberately denied the Papuans their political and human rights.

On December 10, 1999, Dutch Foreign Minister Van Aartson announced that he would initiate a historical re-examination of the circumstances surrounding the Act. Van Middelkoop, the MP who was behind the proposal replied ". . . finally we can look the Papuans straight in the eyes."94 It remains to be seen whether the UN will agree to join the Dutch in returning again to this particular episode from its past.

\footnotetext{
92 Interview by Terrence Markin with Johan B. P. Maramis, Indonesian Mission to UN in 1969, December 3, 1990. Quoted in Markin, "The West New Guinea Dispute," p. 480.

93 Interview by Casale with Ortiz Sanz, December 15, 1999.

94 Algemeen Dagblad (Netherlands), December 10, 1999.
} 